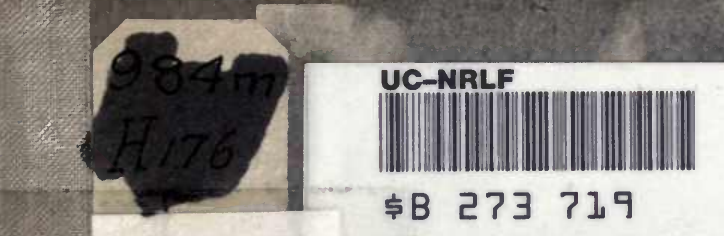

Q K 143 H 25 1915 MAIN

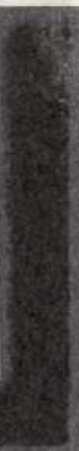

$\frac{\pi}{2}$ 

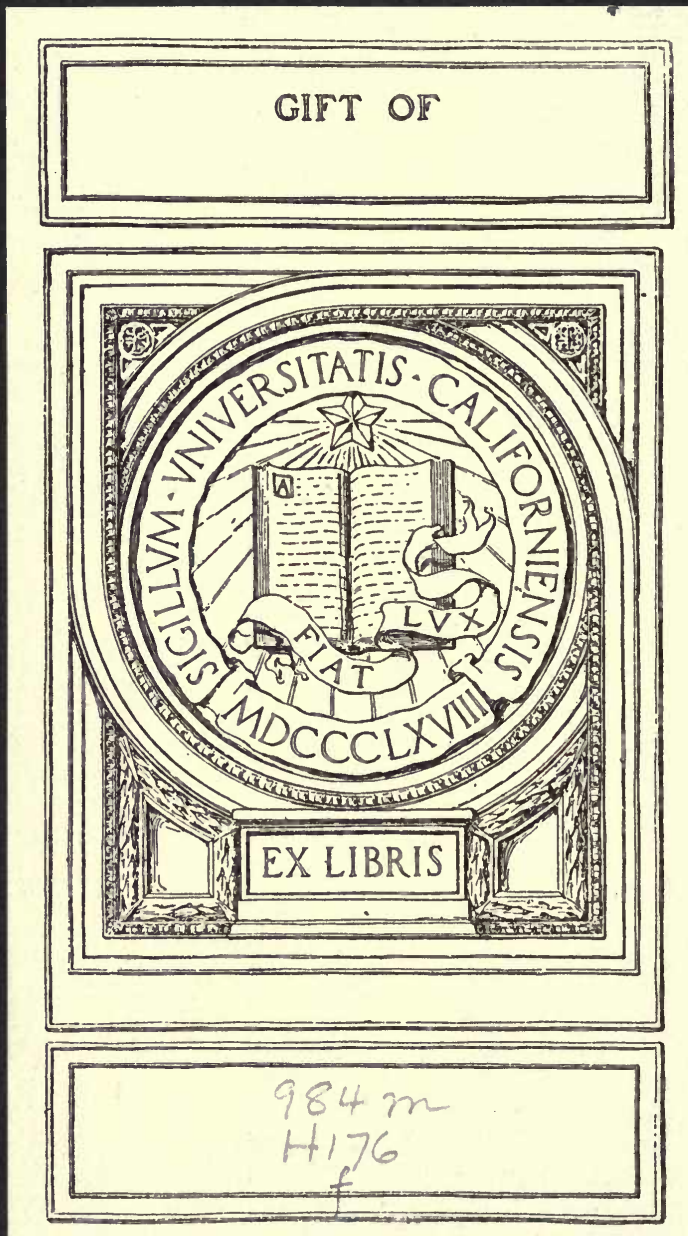


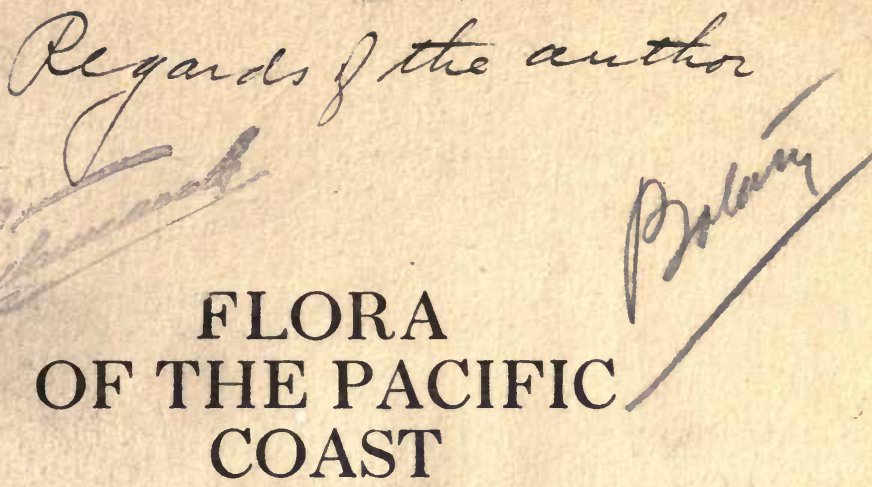

By HARVEY MONROE HALL

Assistant Professor of Botany

University of California

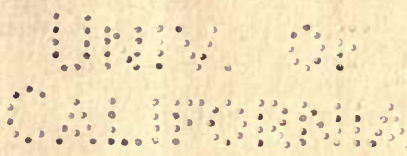

Reprinted from Nature and Science on the Pacific Coast. Published by Paul Elder and Company, San Francisco, 1915. 
$\because \quad 0$

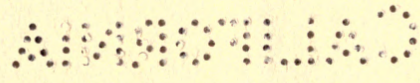




\section{FLORA OF THE PACIFIC COAST}

BY HARVEY MONROE HALL Assistant Professor of Botany, University of California

HE flora of the Pacific Coast offers many attractions to the botanical traveler. No matter

1 what phase of botany may interest him most, whether it be the aesthetic, the systematic, the genetic, or the ecologic, he will find ample material for his studies and a never-ending succession of problems to tax his skill as an investigator. The flowers are more highly colored than are those of most other regions, and the number of species is larger, while fluctuating variations in vegetative characters are exceedingly abundant and often give rise to very dissimilar forms within the species.

The diverse and variable character of the western flora is undoubtedly due in large measure to a wide variety of climatic, soil, and other environmental factors. At the lower altitudes are desert areas where the vegetation is strongly xerophytic and the flora evidently related to that of Mexico, the high mountain summits are likewise arid but the vegetation here is Alpine in character and the flora undoubtedly of boreal origin. Between these extremes are areas of highly diversified topography. Rugged mountains alternate with fertile valleys; deep cañons furnish walls of varying slope and all exposures; there are lakes, swamps, alkaline depressions, and in addition such variety of soils that nearly every class of plants somewhere finds conditions suitable to its needs. The Sonoran, or Mexican, element of the flora occupies most of southern California and extends north through the interior valleys even into Washington. The boreal element is naturally best represented in Washington, Oregon, and Idaho although the boreal zones extend down the whole length of the Sierra Nevada and into southern California. Where the two meet there occurs a mingling of the northern and southern elements and in many places one also encounters a peculiar flora, especially of shrubby species, not closely related to that of any other region and believed by many to be endemic.

In the following account we shall be able to mention the flora of only a few of the more prominent and accessible plant formations. The desert 


\section{Flora of the Pacific Coast}

area is entirely omitted since its flora is described in a succeeding chapter.

Coastal Formations (chiefly of the Upper Sonoran zone).-Except for those places where the bluffs or mountains extend to the water's edge, the shore line exhibits a series of sandy beaches often backed by a belt of dunes of varying width. Here is found a characteristic xerophytic vegetation composed chiefly of perennial herbs and shrubs. Since the floral composition is fairly uniform from north to south one may study these plants equally well near almost any of the beach resorts.

Very characteristic of the dunes are the Abronias, or sand verbenas, of which $A$. umbellata (rose-pink) and $A$. latifolia (yellow) are the most common. The roots of these plants are often much enlarged, thus serving for storage, while the broad opposite leaves are thick and succulent. The most marked examples of succulent herbage, however, are the Mesembryanthemums, or sea figs, the enlarged often trigonous leaves of which serve admirably as water reservoirs. The pale scurfy-leaved saltbushes (Atriplex) and the hairy-coated Franserias ( $F$. bipinnatifida and $F$. chamissonis), bear unmistakable evidence of their xerophytic nature. More beautiful than the humble herbs just mentioned are the bush lupines of the dunes with their attractive racemes of yellow, bluish, or purplish flowers and silvery-pubescent compound leaves. Similarly pleasing are the Oenotheras, the most common of which is $O E$. cheiranthifolia, whose tough woody stems either trail over the dunes or arise reluctantly from them and bear, in addition to their hairy-protected leaves, an almost continuous succession of yellow blossoms. On the southern beaches occur Calandrinia maritima, a succulent glabrous annual with red flowers, and Amblyopappus pusillus, an erect fleshy Composite herb found also on the coasts of Chile. The sand strawberry (Fragaria chilensis), another species which occurs also in Chile, will be found from San Luis Obispo to Vancouver. The dune tansy (Tanacetum camphoratum) is restricted to the beaches and dunes from Monterey to Humboldt, but is replaced on the coast of Oregon and Washington by $T$. huronense. From Monterey northward will be found the beach pea (Lathyrus littoralis) which although botanically a sweet pea, looks much more like a Hosackia or a lupine because of its silkyvillous herbage.

Flora of the Plains and Lower Foothill Slopes (Lower Sonoran and Upper Sonoran zones).-In early springtime, when the sun's warm rays heat up 148 


\section{Flora of the Pacific Coast}

the soil still moist from winter's rain, innumerable annuals cover the plains, first with green, then with a gorgeous array of floral colors and extend up the slopes until lost amid the shrubs of the foothill belt. This is the scene over which poets thrill and botanists despair. For this is the home of the California poppy (of which some claim that there are more than a hundred species), and of the cream-cups, and Phacelias, and Godetias, and Baerias, and tidytips, and a thousand other beautiful but, to the botanist, perplexing groups of closely related species.

Suburban railways from almost any city, from San Diego to Seattle, will carry one into these flowery gardens, but it is in southern California and along the borders of the Great Central Valley that the greatest profusion of flowers is to be seen. One reason for this is the absence of sod-forming grasses, the annuals thus being permitted to occupy the whole area whenever moisture and temperature conditions are favorable.

If the visiting botanist selects the plains or foothill slopes of southern California for his excursion he will be impressed with the preponderance of Composites, indicating perhaps, the close relation with the Mexican flora. Baeria chrysostoma grows in such abundance that it is known as gold-fields. $B$. coronaria is equally plentiful in some parts of San Diego County and both species furnish excellent material for the study of variation as related to environment. Layia, Coreopsis, Chaenactis, and (at San Diego) Pentachaeta are other abundant Composite genera. Because of the large and showy cupshaped flowers, the various species of Calochortus (mariposa lily), a characteristic western genus, are easily found, especially along the foothills. Another liliaceous group, the Brodiaeas, which grow from edible corms and bear umbels of usually bluish flowers, inhabit clay soils. The rare Matilija poppy, well known for its magnificent white flowers, is best seen in the Ojai Vallev, Ventura County, and in Santiago Cañon, Orange County, but it also occurs in masses in Temescal Wash, southeast of Corona, and in San Diego County.

Many of the genera just mentioned may also be found on the coastal slope of middle California, but here there is a larger proportion of grasses and of perennials, consequently the foliage is more luxuriant, and the flowers are less conspicuous. During the spring and summer months, Baerias, Layias and other Composites still dominate certain slopes, such as those around Lake Merced, just south of San Francisco. On down the San Francisco Peninsula 


\section{Flora of the Pacific Coast}

are to be seen extensive fields of Eschscholtzia and Platystemon. Those who journey still farther southward will find all of the foothill slopes around the Santa Clara Valley teeming with attractive and interesting species. To the east and north of San Francisco Bay the hill districts form the chief attraction. Here will be found Brodiaea, Chlorogalum, Sidalcea, Orthocarpus, Castilleia, Wyethia, Nemophila, Lathyrus, and many other genera of showy or otherwise interesting seed plants. Passing northward into Oregon and Washington these formations become of less and less importance. There the coniferous forests predominate.

The Chaparral Flora (Upper Sonoran zone).Chaparral is a term applied in the West to any low and shrubby growth regardless of the species of which it may be composed. Its individuals are literally the "little chaps" as contrasted with the forest trees. It corresponds to the maqui of the Mediterranean region, and to the scrub of Australia. Although it occurs also in other life zones, chaparral is with us preeminently characteristic of the Upper Sonoran, or, as it is often called, the foothill or chaparral belt.

Our Upper Sonoran chaparral is strongly xerophytic in character. The root system is well developed and in many cases harbors bacteria the presence of which is presumably beneficial; the branching is profuse and intricate; the usually narrow evergreen leaves are heavily cutinized, often covered with tomentum (e. g., Artemisia californica, Eriodictyon tomentosum, Malvastrum of several species), or they may assume a vertical position (Arctostaphylos, Dendromecon). Often the herbage is strongly resinous (Ericameria, Baccharis) or coated with a gummy or wax-like layer (Eriodictyon californicum).

In order to observe the many peculiarities of our shrubby vegetation it is necessary to travel only a short distance from the cities and towns usually visited, for chaparral abounds in almost every district except along the northwest coast. In the immediate vicinity of San Diego it is restricted chiefly to northerly slopes of the arroyos, but here are found Mexican species of the Lower Sonoran zone which do not occur much farther north. Such are Viguiera laciniata and Encelia farinosa, both yellow-flowered Composites, the latter ranging north to San Bernardino. Along the foothills from this last-named city to Los Angeles is found a broad chaparral belt in which the chamisal (Adenostoma californica) is very prominent. This narrow-leaved Rosaceous shrub is one of the most abundant in the whole 


\section{Flora of the Pacific Coast}

state and is especially beautiful in summer and autumn when thousands of miles of foothill slope are suffused with the warm reddish-brown tints of its fading bloom. This southern chaparral also includes the scrub oak (Quercus dumosa), many species of Ceanothus, Arctostaphylos, and Artemisia, as well as other elements. Of economic as well as biologic interest are two shrubby species of Salvia, $S$. apiana, the white sage, and $S$. mellifera, known as black sage. Both of these are important bee plants as is also an abundant shrubby Eriogonum ( $E$. fasciculatum). The yellow-flowered tree poppy may be seen at its best on the Santa Ynez Mountains back of Santa Barbara. The Spanish bayonet (Yucca whipplei) is of more general distribution, for it grows on nearly all the lower mountains where its creamy white panicles far overtop the surrounding vegetation, giving to the landscape a unique and pleasing aspect. (See Pl. XX.)

The general appearance as well as the floral composition changes but slightly as we pass northward, except that northerly slopes are given over to broadleaved shrubs and trees of the Transition zone. On the south-facing slopes of Mount Tamalpais, in the vicinity of San Francisco, the dominant shrubs are the same as in the chaparral of southern California. In addition to these one will encounter some species and even a few genera not represented in the south. An example of the remarkable ability of chaparral to re-cover a burned area by means of stumpsprouting may be studied on the south slopes of Mount Tamalpais. In July, 1913, these were swept by a fire which killed to the ground all shrubs over a large area. The present condition is therefore the result of growth since that time.

In the more northerly Coast Ranges the chaparral is confined to the poor soil of dry ridges which occur here and there in the redwood belt and to the arid districts beyond the immediate influence of coast fogs. The San Joaquin and Sacramento valleys are completely encircled by a chaparral belt which extends up to the forests of the Coast Ranges and of the Sierra Nevada. Therefore any excursion into the inner North Coast Ranges, or from the Great Central Valley to any of the mountain resorts will necessarily lead one through districts where chaparral may be studied to advantage.

In northeastern California, Oregon, and Washington is encountered a more open formation, characteristic of the Columbia and Great basins. Here the shrubs are low and often pale or gray in color. The most abundant species are the sagebrush 


\section{Flora of the Pacific Coast}

(Artemisia tridentata), rabbit-brush (Chrysothamnus of several species), hop sage (Grayia spinosa), antelope brush (Purshia tridentata), and in alkaline soil black greasewood (Sarcobatus vermiculatus).

The Mountain Flora (Transition, Canadian, Hudsonian, and Arctic-Alpine zones).- In the mountainous districts the most important life zone is the Transition, so-named because here the boreal and the southern elements of the flora meet. Except along the coastal strip it coincides in general with the yellow pine belt. Here the botanical traveler will find a delightful and exhilarating climate during the summer months. If he comes from the eastern states most of the genera and some of the species will be already familiar to him, if from the north or from northern Europe he will feel more at home, botanically, in the higher zones. Vast areas of yellow pine forest are easily accessible by wagon road or trail from all the mountain settlements and resorts, while those who desire more strenuous mountaineering will find ample test for their skill.

In the open forests will be found a scattering growth of flowering herbs. These increase in abundance as the trees become better spaced, thus admitting more light. Pentstemons are plentiful, especially in the south. Monardellas, Gilias, several species each of Pedicularis, Lathyrus, Hosackia, and many other genera are not uncommon. Thick-stemmed saprophytes like Pterospora, Pleuricospora, Corallorhiza, and Pyrola aphylla force their way through the carpet of pine needles. The most popular of these saprophytes is the snow plant (Sarcodes sanguinea) the thick red stalks of which appear soon after the snow has melted and remain as conspicuous elements until autumn. Although not abundant it may be expected anywhere in this zone from southern California to Oregon.

But it is only in the forest openings that one finds flowering plants in profusion. Gravelly slopes along rocky outcroppings and exposed ridges are the most productive. Such localities may be yellow with Eriogonum and Eriophyllum, both of which western genera are represented by many species, or blue with Erigerons or Asters, or brilliant with several sorts of Pentstemon, but always with an admixture of many species belonging to other genera.

Here and there the forest opens up to make room for a mountain meadow the composition of which will vary with the moisture content of the soil as well as with geographical position. A small meadow in Butte County, California, may be described as typical of those to be found in the Sierra Nevada. 


\section{Flora of the Pacific Coast}

Here the most prominent species is Castilleia miniata the numerous red spikes of which impart a rich warm color to the vegetation. Next in importance are the white heads of Selinum, which overtop all else save where the clumps of lupine (Lupinus polyphyllus) carry their blue racemes still higher. On one gentle southerly slope the elephant heads (Pedicularis attollens) are very conspicuous and the whole meadow is punctuated with the white spikes of the Sierra rein-orchis (Habenaria leucostachys). More than twenty other species in addition to the grasses and rushes also inhabit this meadow.

Comparatively dry meadows and grass-land are also frequent, affording excellent opportunity for researches upon the relation of environment to distribution and structure.

The riparian and bog formations have each their characteristic species, but mention can be made only of the California pitcher plant (Darlingtonia californica). This noted insectivorous species grows in boggy meadows of northern California and southern Oregon. It may be most conveniently examined at the "18th crossing," a few miles south of Sisson on the San Francisco and Portland line of the Southern Pacific Railroad, or in Butterfly Valley, just south of Keddie on the line of the Western Pacific Railroad. The plants are much finer and more abundant at this latter locality.

Passing over the Canadian and Hudsonian zones we may now take a brief survey of the flora above timber-line. The Arctic-Alpine zone, the lower limit of which is marked by timber-line, scarcely occurs in southern California. On southerly slopes it begins at an average altitude of 11,000 feet in the southern Sierra Nevada, at 9500 feet on Mount Shasta, and at about 6500 feet in Washington. Throughout its whole extent the vegetation and the flora are fairly uniform. In this zone all plants have deep perennial roots and low tough stems. The leaves, closely huddled near the base or along the short stems, are heavily cutinized. Among the characteristic species, all of boreal origin, may be mentioned the Arctic willow (Salix arctica var. petraea) with stems only two or three inches high; Cassiope mertensiana with thick overlapping leaves and dainty pendant flowers; the Alpine sorrel (Oxyria digyna), well known in Arctic and Alpine districts around the world; Polemonium eximium, with showy blue flowers (replaced in Washington by $P$. elegans), and a number of Composites, mostly with yellow flowers. This is only the beginning of a long series of species which might be enumerated. 


\section{Flora of the Pacific Coast}

The large number of forms, the remarkable adaptations to so rigorous a habitat, and the brilliancy of the colors displayed all conspire to make a study of the Alpine flora an exceedingly attractive occupation. The highest summits are beyond the reach of seed plants, but the rocks support a meager lichen flora.

Flora of the Northwest Coast (mainly of the Humid Transition area).-The term Northwest Coast is here used to designate the coastal slope of Washington and Oregon, west of the Cascade Mountains, and northern California west of the Coast Ranges. Because of its moist climate and equable temperature this coastal strip sustains the densest forests in North America. Save on the open prairies, which occur in limited number, the herbaceous flora is composed almost entirely of broad-leaved mesophytes. These, however, are exceedingly luxuriant. In the densest shade the ground is covered with mosses and ferns, of which a sword fern (Polystichum munitum) is the most abundant. Here also are found the huckleberries (Vaccinium parvifolium and $V$. ovatum). Where the forest is more open the sword fern is replaced by the common brake (Pteris aquilina), and two sub-shrubs become common, namely, the Oregon grape (Berberis nervosa) and the salal (Gaultheria shallon). The salal is especially prominent, often covering the forest floor for miles with almost impenetrable thickets. Along stream-borders from Santa Cruz northward to near the Oregon line will be found the delightfully fragrant western azalea (Rhododendron occidentale), while the California rose bay ( $R$. californicum) is partial to rugged mountain sides and grows as far north as British Columbia.

In favorable situations, particularly in the more southerly redwood belt. we find a good representation of herbaceous shade-plants. Several species of Heuchera and Tellima throw out their rounded leaves in broad rosettes, and twin-flowers (Linnaea borealis) overhang the moss-covered logs. Vancouveria, with fern-like foliage but flowers so odd that they are termed inside-out flowers, grow in small clumps on the better-drained slopes. Here also trail the wood-loving Whipplea (W. modesta) and the yerba buena (Micromeria chamissonis), the trailing mint which gave to San Francisco its earliest name. On wet bottom-lands and along streams one will find the salmon berry (Rubus spectabilis), the red-berried elder (Sambucus callicarpa), and several species of Ribes. The devil's club (Echinopanax horridum), a foetid prickly red-fruited shrub with 
Flora of the Pacific Coast

large palmately lobed leaves, also belongs to this association but does not occur south of Oregon.

\section{LOCALITIES OF SPECIAL BOTANICAL INTEREST}

Tucson, Arizona. Here are located the Desert Botanical Laboratory of the Carnegie Institution and the University of Arizona. The surrounding territory affords splendid opportunities for the study of desert flora.

San Diego, California. The mesa flora is here of particular interest and is abundant to the north and east of the exposition grounds. Visitors to Tia Juana should take private conveyance in order to drive to the westernmost boundary monument, where Agave shawii may be seen, and to return by way of the Silver Strand in order to study the beach flora. Back of San Diego will be found a highly interesting mountain region, dominated by Cuyamaca Peak, considerable areas of which extend well into the yellow pine belt. El Campo, forty miles east from San Diego, is in the midst of a chaparral flora of exceptional interest since desert and Mexican elements are much in evidence. Annual flowering plants are abundant in springtime, filling in all spaces left vacant by the shrubs which are themselves often brilliant with the blood-red flowers of a climbing Lathyrus. El Campo is on the San DiegoEl Centro stage line. Those traveling by private conveyance should return via Pine Valley and the Viejas Grade. The desert flora may be observed by continuing easterly to Mountain Springs

Riverside, California. The mesa and foothill flora may be examined to best advantage by taking the electric cars to the Bloomington plains or the daily San Jacinto auto-bus to "the fill" on Box Springs Grade and walking back cross-country to Eighth and Ottawa streets where return transportation may be had.

Redlands, California. San Timoteo Cañon, back of Smiley Heights, should be explored for its profusion of annuals intermixed with chaparral. Mill Creek Cañon is very interesting botanically.

San Bernardino, California. The electric line to Arrowhead Hot Springs will carry one to the heart of the chaparral belt. Annuals grow in abundance around the mouth of Waterman Cañon, crossed by the same line.

Los ANgeles and Pasadena. Numerous electric lines lead to Hollywood, Altadena, Sierra Madre, and other foothill stations as far east as San Bernardino. The Mount Lowe Railway takes one into the edge of the yellow pine belt in a few hours. More will be 


\section{Flora of the Pacific Coast}

seen, however, if one has time to make the ascent by train or to drive (by auto or team) up the Santa Anita grade. Redondo, Playa del Rey, and other beach resorts afford opportunity for the study of the beach and dune flora.

Santa Barbara. From the mission one may explore Mission Valley or, better, follow the Mountain Drive. Here will be found the rare and showy Venegasia, a sub-shrub much more handsome than the sunflowers, to which it is related. The Tunnel Trail to the summit of the Santa Ynez Mountains affords a delightful day's trip for the observation of chaparral and annual flowering plants.

San Francisco and Environs. Dune and beach plants are abundant south of Golden Gate Park and at Land's End. Electric lines running south to San Mateo, etc., lead through many fields of showy annuals. These are especially luxuriant on the slopes a short distance west of Millbrae. The foothills back of Stanford University are very attractive botanically and easily reached from Palo Alto.

Mount Tamalpais dominates the peninsula north of the Golden Gate and should be visited by all botanists. Salt-marsh plants abound between the bay shore and the foot of the mountain. From Mill Valley the railroad winds through a sea of chaparral which extends to the very summit. Both the peak and Muir Woods, a redwood reservation with a characteristic vegetation, may be visited in one day but this is not advisable. The enthusiast will much prefer the trails from Mill Valley, or he may take the train to the summit or to Muir Woods and walk back.

On the easterly shore of San Francisco bay numerous electric lines lead to the hills and cañons where good collecting abounds. The Oakland and Antioch Railway pierces the Oakland Hills and so transports one in less than an hour's time to localities where the vegetation is still in its original condition. Pinehurst Station, in Redwood Cañon, is especially recommended. From here a two-mile walk brings one to Moraga, where return trains may be taken.

Ukiah, California. This is in the heart of the inner Coast Ranges. The Terraces, where many native plants are grown under cultivation, lie some seven miles to the east up an interesting cañon. Lake County resorts are reached by stage from either Ukiah or Calistoga.

Yosemite Valley. The best botanizing is on the slopes around the valley borders and away from the popular trails. The Tenaya trail above Mirror Lake

156 


\section{Flora of the Pacific Coast}

is recommended. Bog and shade plants abound near Happy Isles and Iron Spring. The wise enthusiast will use the trails early in the day and avoid the parties "under guidance" as far as possible. The most productive fields are around the valley's rim. One should make headquarters for a portion of his time at Glacier Point, whence the rich flora of Sentinel Dome as well as that of numerous meadows and bogs may be easily explored. In order to reach the Alpine zone of the High Sierra from Yosemite it is necessary to make a packing trip of several days' duration.

LAKE TAhoe. The Sierra Nevadan flora may be conveniently investigated from any of the numerous resorts around the Lake. Deer Park Springs and the resorts from Emerald Bay to Fallen Leaf Lake are well situated for plants of the forests. Glen Alpine affords more ready access to the higher zones and especially to the Alpine flora of Pyramid, Ralston and other high peaks.

Mount Shasta. This mountain is usually ascended from Sisson. The flora of the middle zones is very rich but the Alpine flora is disappointing.

Summit, Placer County, California. Passengers on the Central Pacific Railway may stop over here and examine the sub-alpine flora. Peaks above timber-line are within a day's walk and Donner Lake lies two miles to the east.

EUREKA, California. The flora of the redwood belt is conveniently observed about Eureka and Arcata. Samoa Peninsula with a rich beach and dune flora is also within easy reach.

Portland, Oregon. A trip should be taken up the Columbia River, one way by boat, the other by train. Abundant plant material may be obtained by stopping at Cascade Locks. The coast may be visited at Seaside which may be reached by boat or rail from Portland. This is a day's trip each way. The beach may also be reached from Albany by rail to Newport, and from Eugene by rail and boat to Florence. The available plant life of dune and down and bog is abundant.

Crater Lake, Oregon. This national park may be reached from Medford by auto stage. The trip is of great botanical interest and there is an especially good display of flowering plants at the summit. Those who have sufficient time should by all means make the trip by private conveyance.

TACOMA. A visit to American Lake and vicinity by any of the several lines is recommended. The running time is less than an hour and both prairie and forest plants will be found in abundance along 


\section{Flora of the Pacific Coast}

the route. At Tacoma one will find excellent opportunity to study the vegetation of the salt marshes. Mount Rainier, which extends above the limit of flowering plants is reached by stage. Those who take the Rainier trip will find an abundance of alpine species in and around Paradise Park.

Seatrle. The flora of the coniferous forest formation may be reached by any line that extends beyond the cleared districts. The Lake Washington district is recommended.

\section{REFERENCES}

ABRAMS, L. R.

1904. Flora of Los Angeles and vicinity. (Stanford University Press), pp. 1-xi, 1-474. (Descriptions and keys for all the spermatophytes.)

1910. A phytogeographic and taxonomic study of southern California trees and shrubs. Bull. N. Y. Botanical Garden, vol. 6 , pp. $300-485,10$ pls. (Keys and distribution.)

CARNEGIE INSTITUTION OF WASHINGTON.

Numerous publications, treating especially of desert plants. COVILLE, F. V.

1893. Botany of the Death Valley Expedition. Contrib. U. S. Nation. Herb., vol. 4, pp. 1-vili, 1-363, 22 pls., map.

EASTWOOD, ALICE.

1902. A Flora of the South Fork of Kings River. Publ. Sierra Club, no. 27, pp. 1-96, 9 figs. In text. (Descriptions of ferns and flowering plants.)

GRAT, A., BREWER, W. H., and WATSON, S.

1876-1880. Botany of Callfornia. Geological Survey of California. (Boston, Little, Brown, and Company), vol. 1 , pp. $1-x x, 1-628$; vol. 2 , pp. 1-xv, 1-559. (Descriptions and keys.)

HALL, H. M., and HALL, C. C.

1912. A Yosemite flora. (San Francisco, Paul Elder and Company), pp. 1-vif, 1-282, 11 pls. and 171 flgs. in text. (Descriptions and keys for ferns and flowering plants of the Yosemite National Park.)

HOWELL, T.

1897. A flora of Northwest America. (Portiand, Ore., J. K. Gill Co.), pp. 1-816. Descriptions of spermatophytes of Oregon, Washington, and Idaho.

JEPSON, W. L.

1911. A flora of western middle California. Second Ed. (San Francisco, Cunningham, Curtiss \& Weich), 515 pp. (Descriptions and keys for all spermatophytes.)

1909-1914. A flora of Callornia. (San Francisco, Cunningham, Curtiss \& Welch), Part I, pp. 33-64, figs. 1-14; Part II, pp. 337-368, flgs. 61-65; Part III, pp. 65-192; Part IV, pp. 369-464, flgs. 66-91; Part V, pp. $465-528$, figs. $92-105$.

PARSONS, M. E., and BUCK, M. W.

1909. The wild flowers of Callfornia. (San Francisco, Cunningham, Curtiss \& Welch), pp 1-cvi, 1-417. (Descriptions and illustrations of the more conspicuous species.)

PIPER, C. V

1906. Flora of the State of Washington. Contrib. U. S. Nation. Herb., vol. 11; pp. 1-637, pls. I-XXII, map.

UNIVERSITY OF CALIFORNIA.

Publications in Botany, vols. 1-6. (Berkeley, Univ. Calle. Press.) (Contain numerous papers and monographs on west American plants.) 


\section{CONTENTS}

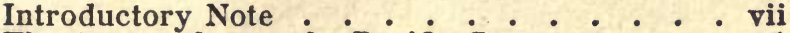

The Approaches to the Pacific Coast . . . 1

Frederick J. Tegantr. Associate Professor of

Pacific Coast History, University of California.

Spanish Settlements on the Pacific Coast .

Charles E. Chapman. Sometime Traveling Fellow in Pacific Coast History, N. S. G. W., University of California.

Historical Sketch of the Panama Canal .

RUdOLPH J. TAUSSIG. Secretary, Panama-Pacifie International Exposition, San Francisco.

Weather Conditions on the Pacific Coast AlEXANDER MCAdIE. Abbott Lawrence Rotch Professor of Meteorology, Harvard University.

Physiographic Geography RULIFr S. HoLwAY. Associate Professor of

Physical Geography, University of California.

Geology of the West Coast Region of the United States . • . - . . . . .

C. F. Tolman, JR. Associate Professor of Economic Geology, Stanford University.

Earthquakes

J. C. BranNER. President, Stanford Úniversity.

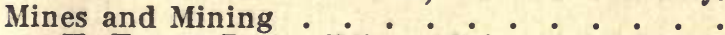
H. Foster BaIN. Editor, Mining and Scientific Press, San Francisco.

Petroleum Resources and Industries of the $\mathrm{Pa}$ cific Coast

RALPH ARNOLD. Consulting Geologist and Petro-

leum Engineer, Los Angeles.

Significant Features in the History of Life on the Pacific Loast . . . . . . . . JOHN C. MERRIAM. Professor of Palaeontology and Historical Geology, University of California.

The Vertebrate Fauna of the Pacific Coast . . . 104 JOSEPH GRINNeLL. Director, Museum of Vertebrate Zoology, University of California.

Fishes of the Pacific Coast . . . . . . 115

DAvid STARR JoRdaN. Chancellor, Stanford University.

Marine Biology on the Pacific Coast . . . 124

Charles ATwOOD KoFoID. Professor of Zoology,

University of California.

Oceanic Circulation and Temperature Off the Pacific Coast . . . . . . 133

Grorge F. McEwen. Scripps Institution for Biological Research, La Jolla, California.

Insects of the Pacific Coast . . . . . . . 141

Vernon L. Kriloga. Professor of Entomology,

Stanford University. 
THIS BOOK IS DUE ON THE IAST DATE STAMPED BEIOW

AN INITIAL FINE OF 25 CENTS WILL BE ASSESSED FOR FAILURE TO RETURN THIS BOOK ON THE DATE DUE. THE PENALTY WILL INCREASE TO 50 CENTS ON THE FOURTH DAY AND TO \$1.00 ON THE SEVENTH DAY OVERDUE.

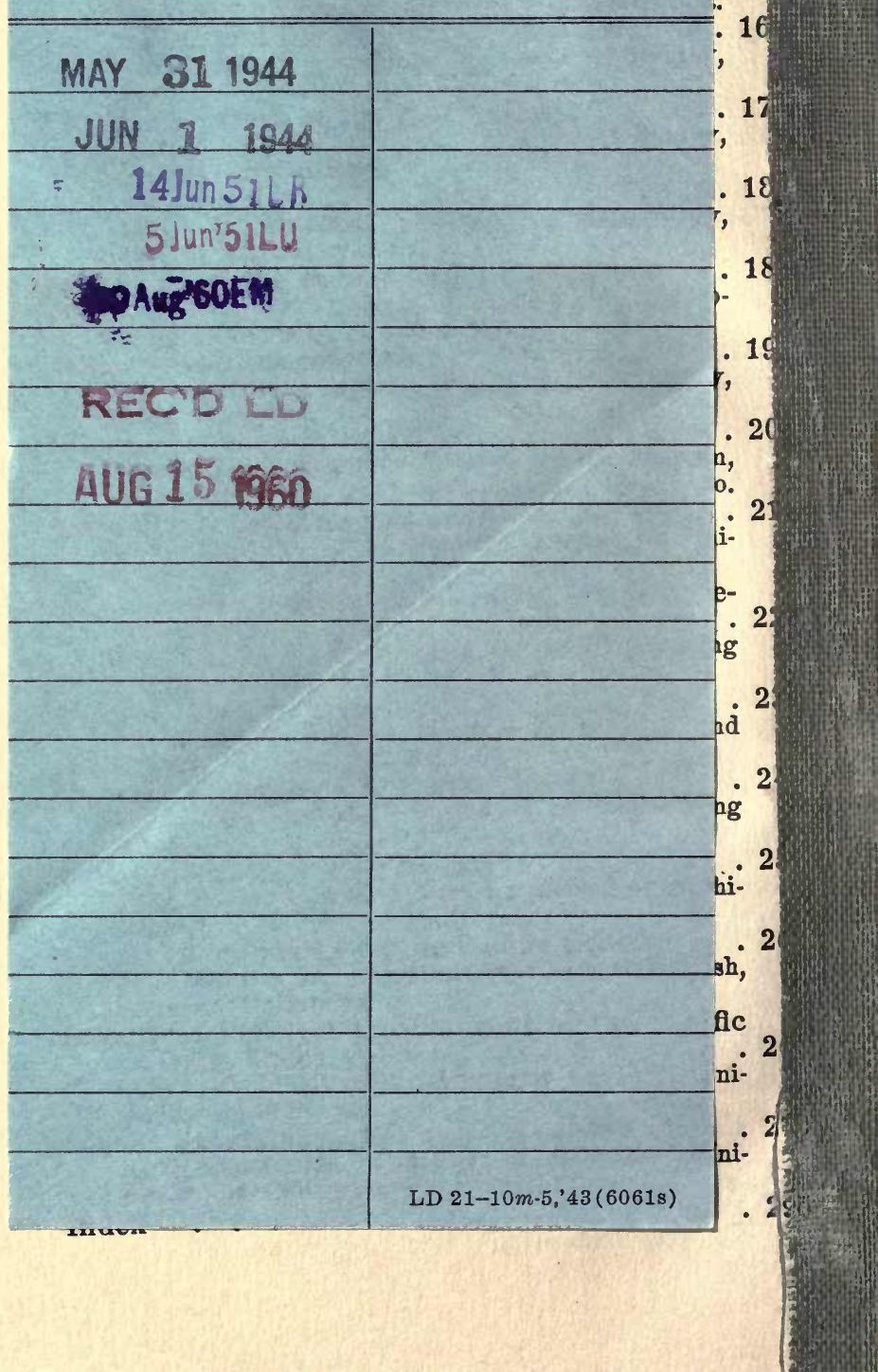


Gaylord Bros. Makers Syracuse, N. Y. PAT. JAN. 21, 1908

\section{U. C. BERKELEY LIBRARIES}

C04557304b

\section{4}

UNIVERSITY OF CALIFORNIA LIBRARY 
